\title{
A RETROSPECTIVE ANALYSIS AND MONITORING OF THE SPREAD OF COVID-19 IN NIGERIA
}

EDIKE NNAMDI, BRAIMAH JOSEPH ODUNAYO AND AGBEDEYI ODIMIENTIMI DESMOND

(Received 12 September 2019; Revision Accepted 3 July 2020)

\begin{abstract}
This study is aimed at analyzing and monitoring the spread of COVID-19 pandemic in Nigeria using some selected statistical tools. The data used for the study comprised of daily reported new cases of the pandemic as of 18th August 2020. The data was sourced from the Nigeria Center for Disease Control (NCDC). Some time-series models were used to estimate the trend and make forecasts of the prevalence of the pandemic while control charts were employed in monitoring the variations in the mean number of new COVID-19 cases reported daily. The Individual values, Moving Average and Exponentially Weighted Moving Average (EWMA) control charts were employed for this purpose. The study revealed that, although efforts to contain the spread of the virus are yielding some positive results, the daily spread of the virus in Nigeria is out of control. It was recommended that the government should intensify measures to curb the spread of the virus in the country.
\end{abstract}

KEYWORDS: COVID-19, pandemic, control charts, Trend, EWMA, Moving Average.

\section{INTRODUCTION:}

The novel coronavirus disease (COVID-19) is known to be caused by a virus strain known as SARS-CoV-2[1,2]. It was first discovered in Wuhan in Hubei Province of China in December 2019.

On 31 January 2020, following the developments of the COVID-19 pandemic in mainland China and other countries worldwide, the federal government of Nigeria set up a Coronavirus Preparedness Group to mitigate the impact of the virus if it eventually spreads to the country[4,5]. On the same day, the World Health Organization listed Nigeria among other 13 African countries identified as high-risk for the spread of the virus[6].

The first confirmed case of the pandemic in Nigeria was announced on 27 February 2020, when an Italian citizen in Lagos tested positive for the virus. On 9 March 2020, a second case of the virus was reported in Ewekoro, Ogun State, a Nigerian citizen who had contact with the Italian citizen. Since the confirmation of the index case, the spread of the virus has been on the increase across the nation with Lagos, Abuja, and recently, Kano as the most affected states in Nigeria.

Though the coronavirus is a serious threat to the nation and the world at large, it has been noted that its fatality rate in Nigeria is relatively low compared to its rate of spread[3]. This study, therefore, attempts to analyze and monitor the spread of the novel coronavirus in Nigeria using some basic statistical tools.

\section{MATERIALS AND METHODS \\ Data}

The data for this study are the daily reported laboratoryconfirmed cases of COVID-19 pandemic in Nigeria as at $18^{\text {th }}$ August 2020. The data was sourced from the Nigeria Center for Disease Control (NCDC). Trend plots, Individual control chart (I-Chart), Moving Average and Exponentially Weighted Moving Average (EWMA) control charts were used to monitor the spread of the novel coronavirus in the country.

\section{Trend Analysis}

A trend shows the general tendency of the data to increase or decrease during a long period. It can be seen as a smooth, general, long-term, average tendency. It is not always necessary that the increase or decrease is in the same direction throughout the given period [8]. Researchers also observed that the tendencies may increase, decrease, or stable in different sections of time. In this paper, we employed the quadratic and the S-curve in studying the trend of daily new laboratory-confirmed cases of COVID-19 in Nigeria from February $28^{\text {th }}$ to August $18^{\text {th }}, 2020$.

\section{Control Charts}

This paper employed the use of Control charts in monitoring the spread of COVID-19 in Nigeria. The Individual control chart (I-Chart), Moving Average and Exponentially Weighted Moving Average (EWMA)

Edike Nnamdi, Department of Mathematics, Ambrose Alli University, Ekpoma, Nigeria.

Braimah Joseph Odunayo, Department of Mathematics, Ambrose Alli University, Ekpoma, Nigeria.

Agbedeyi Odimientimi Desmond, Department of Mathematics and Statistics, Delta State Polytechnic,

Ogwashi-uku, Nigeria. 
control charts were used for this purpose

\section{Individual values control chart}

As with other control charts, the individuals (IndX) control chart consists of points plotted with the control limits or natural process limits. These limits reflect what the process will deliver without fundamental changes. [9]. Points outside of these control limits are signals indicating that the process is not operating as consistently as possible; that some assignable cause has resulted in a change in the process. Similarly, runs of points on one side of the average line should also be interpreted as a signal of some change in the process.

Unlike other control charts, the normal distribution is not assumed nor required in the calculation of control limits. Thus making the IndX chart a very robust tool. This is demonstrated by Wheeler using real-world data [10,11] and for some highly non-normal probability distributions. [12]

The plotted points for the individuals' control chart are each point observation, $x_{i}$

$$
\begin{aligned}
& \text { Control Limits } \\
& \text { Centerline }(C L)=\mu \\
& \text { UpperControlLimit }(U C L)=\mu+k \sigma \\
& \text { LowerControlLimit }(L C L)=\mu-k \sigma
\end{aligned}
$$

where $\mu$ is the process mean,

$\sigma$ is the process standard deviation, and $k$ is the amount of shift in units of standard deviation. Usually $k$ is assumed to be $k=3$

The Moving Average Control Chart is a time-weighted control chart that is constructed from a basic, unweighted moving average. It is often advisable to use the moving average control chart when you desire to quickly detect a change or shift in the process since it is more sensitive to shifts in the process than the traditional average and range control charts (i.e., $\underline{\mathrm{X}-\mathrm{b} \text { - }}$ and $\mathrm{R})$.

\section{Control Limits}

The control limits are calculated as follows. Note that these limits apply for periods greater than or equal to 3 .

Centerline $(C L)=\mu_{0}$

UpperControlLimit $(U C L)=\mu_{0}+\frac{3 \sigma}{\sqrt{ } w}$

LowerControlLimit $(L C L)=\mu_{0}-\frac{3 \sigma}{\sqrt{w}}$

where $\mu_{0}$ is the target value of average or the overall average of the data that will be used for the center line, $\sigma$ is the standard deviation of the moving average, and $\mathrm{w}$ is the span of the values (three in this case).

\section{Exponentially Weighted Moving Average (EWMA) Control Chart}

The exponentially weighted moving average at location $j$ is defined by the recursive equation:

$$
E W M A_{j}=\lambda x_{j}+(1-\lambda) E W M A_{j-1}
$$

for individual data or by

$$
E W M A_{j}=\lambda \bar{x}_{j}+(1-\lambda) E W M A_{j-1}
$$

For data collected in subgroups, $\lambda$ is called the smoothing parameter of the chart $0<\lambda<1$. For this study, the smoothing parameter is arbitrarily set at 0.8 . This ensures that the effects of the old figures on the EWMA values are readily dampened and more weight given to newer values. Like the CUSUM scheme, the $\mathrm{EWMA}_{\mathrm{j}}$ at $\mathrm{j}=1$ is initialized to be zero

(i.e. $E W M A_{0}=0$ ).

\section{Results and Discussions}

In this section, we present the results obtained from the analysis. Below is a graphical representation of the data collected for the study.

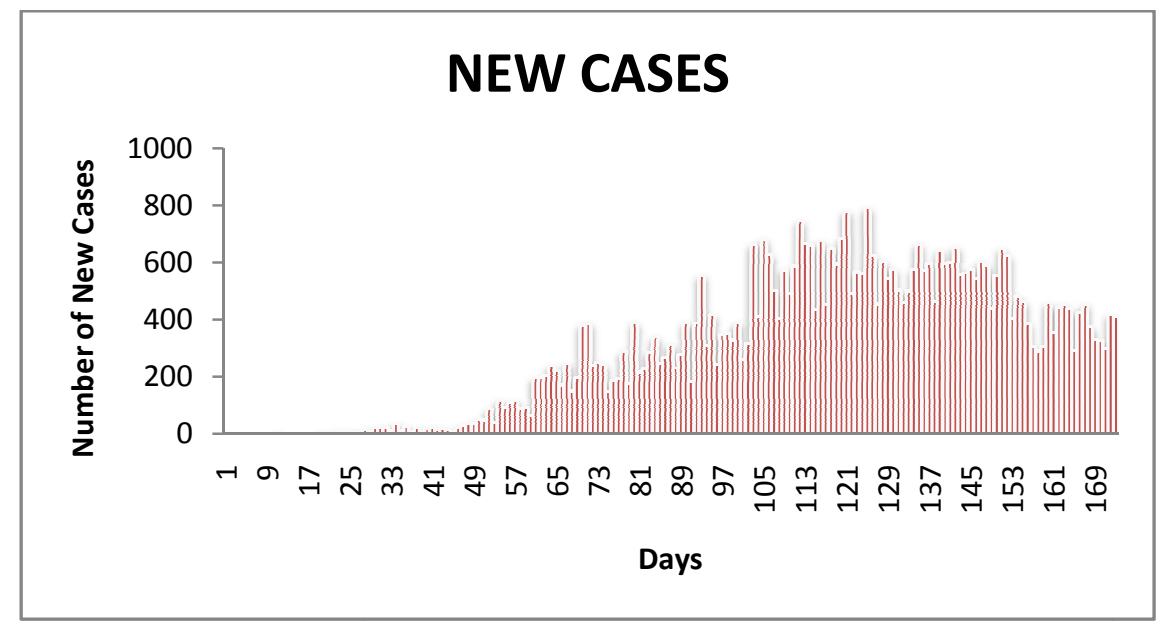

Figure 1: Bar chart showing daily lab-confirmed cases of COVID-19 as at $18^{\text {th }}$ August 2020 
Figure 1 above shows the daily lab-confirmed cases of COVID-19 recorded in Nigeria as at $18^{\text {th }}$ August 2020. From the figure, we observe a steady rise in the number of infected persons until around day 118 to 125 representing the period between $24^{\text {th }}$ June to $1^{\text {st }}$ July 2020, after which we observed a general decline in the daily confirmed cases till $18^{\text {th }}$ August 2020.

\section{Time Series and Trend Analysis}

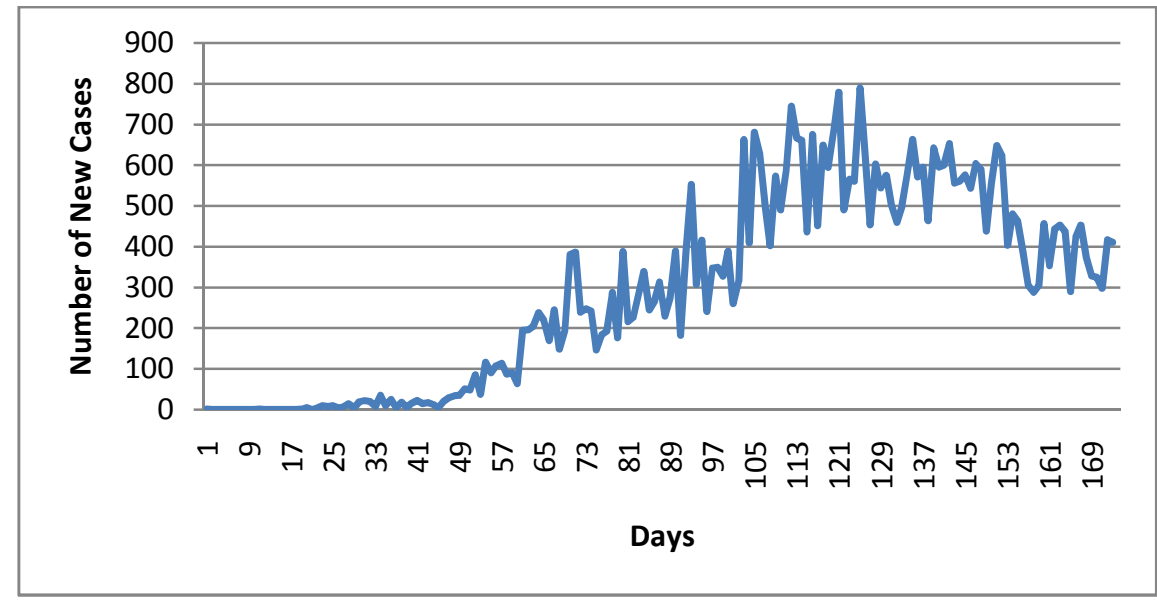

Figure 2: Trend plot of daily lab-confirmed cases of COVID-19 as at $18^{\text {th }}$ August 2020

Figure 2 above shows the trend of daily lab-confirmed cases of COVID-19 recorded in Nigeria as at $18^{\text {th }}$ August 2020. From the figure, we observe a steady rise in the number of infected persons per day. This trend peaked around day 118 to 125 representing the period between $24^{\text {th }}$ June to $1^{\text {st }}$ July 2020 , and thereafter declined till $18^{\text {th }}$ August 2020.

$$
Y_{t}=-174.3+8.086 t-0.02388 t^{2}
$$

This fitted model showed a Mean Absolute Percentage Error (MAPE) of 321.6, Mean Absolute Deviation (MAD) of 97.4, and a Mean Squared Deviation (MSD) of 13,903.6. The model was used to make a 74-day forecast of daily confirmed COVID19 cases in Nigeria and the result presented in Table 1, page 161.

\section{Quadratic Trend Model}

The quadratic trend model was fitted to the number of daily confirmed new cases of COVID-19 in Nigeria. The fitted quadratic model is given as:

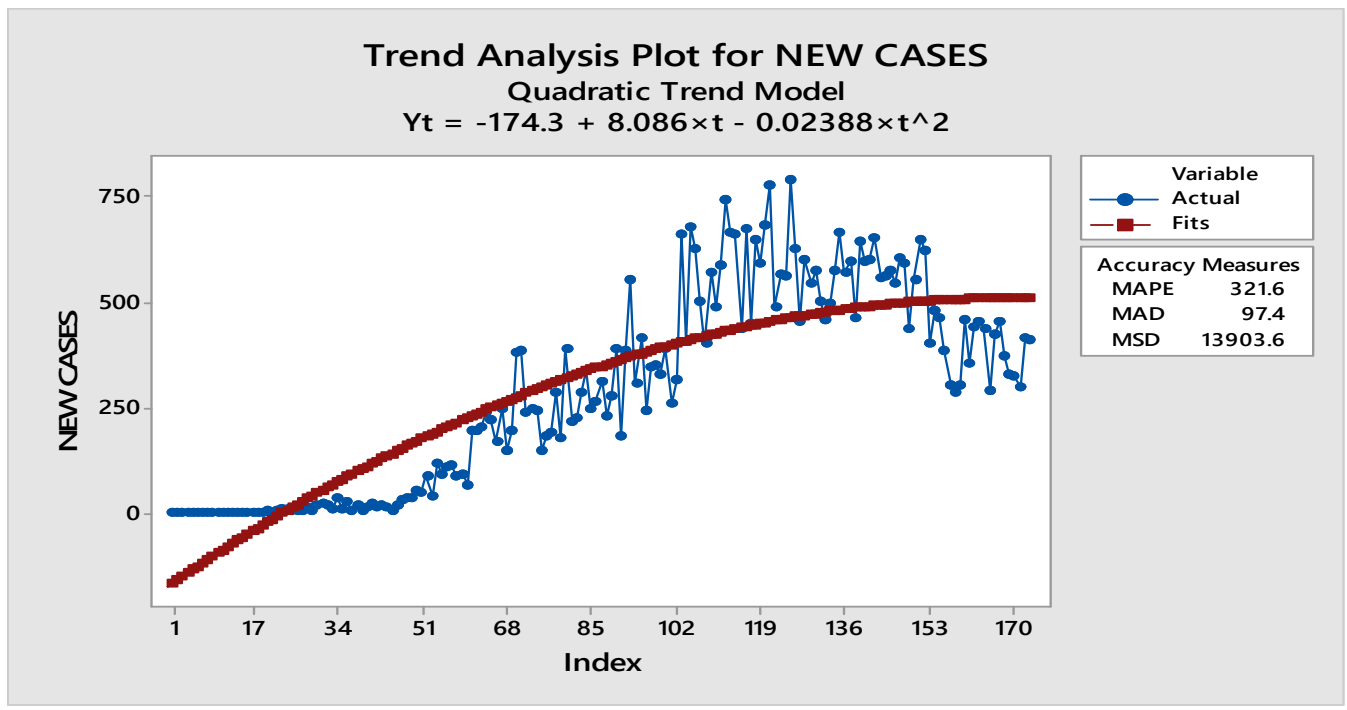

Figure 3: Quadratic Trend model for daily lab-confirmed cases of COVID-19 as at $18^{\text {th }}$ August 2020 
The Pearl-Reed logistic (S-curve) Trend Model We also fitted the S-curve trend model to the number of daily confirmed new cases of COVID-19 in Nigeria. The fitted Pearl-Reed model is given as:

$$
Y_{t}=\frac{10^{4}}{20.6544+4250.40\left(0.9321^{t}\right)}
$$

This fitted model showed a Mean Absolute Percentage over the quadratic model, having smaller values of Error (MAPE) of 57.93, Mean Absolute Deviation (MAD) of 68.99, and a Mean Squared Deviation (MSD) of 9,796.34. This shows better performance of the model MAPE, MAD, and MSD than that of the fitted quadratic model. The model was also used to make a 74-day forecast of daily confirmed COVID-19 cases in Nigeria.

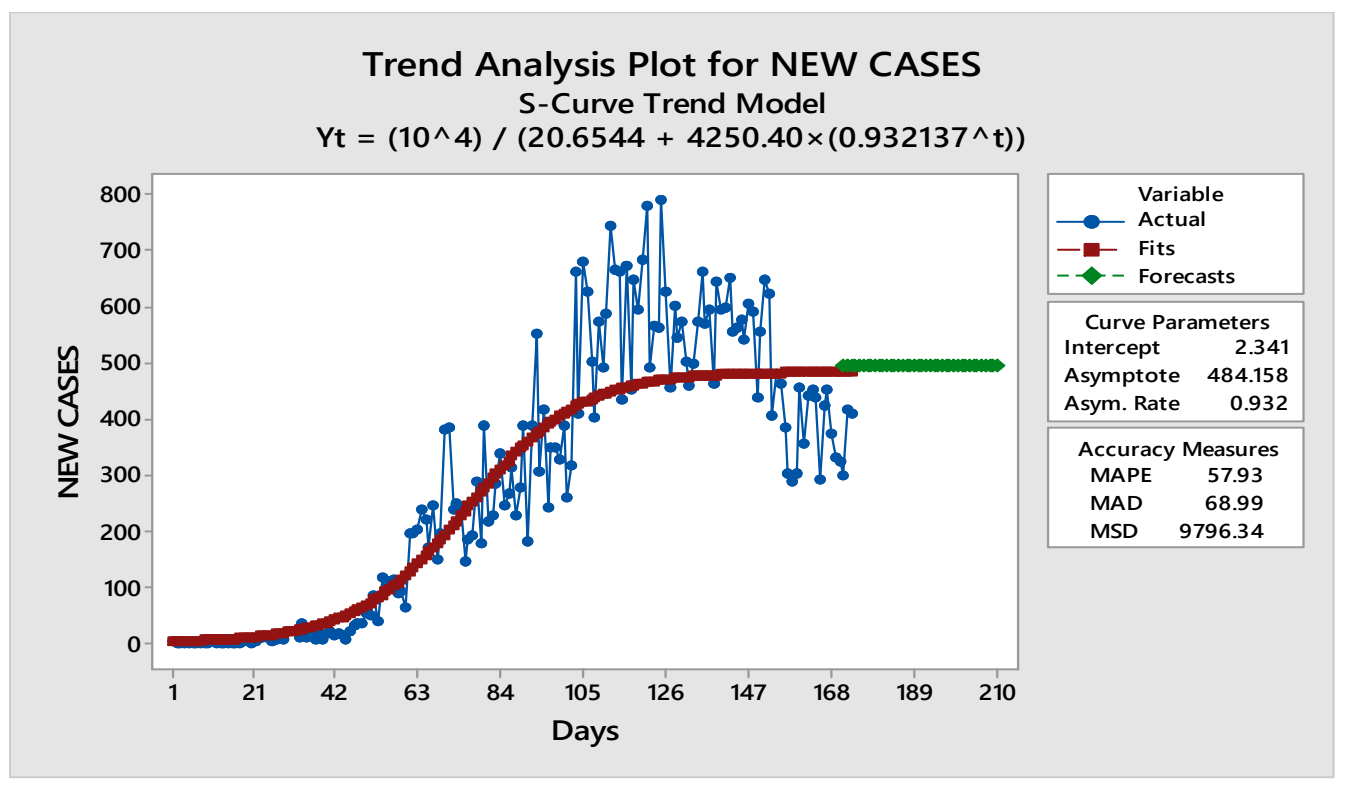

Figure 4: Pearl-Reed logistic (S-curve)model for daily lab-confirmed cases of COVID-19 as at $18^{\text {th }}$ August 2020. 
A RETROSPECTIVE ANALYSIS AND MONITORING OF THE SPREAD OF COVID-19 IN NIGERIA

Table 1: 74-day forecast of daily lab-confirmed cases of COVID-19 using Quadratic and Pearl-Reed logistic

(S-Curve) Model

\begin{tabular}{|c|c|c|c|c|c|c|c|c|}
\hline Date & $\begin{array}{l}\text { Quadratic } \\
\text { Model }\end{array}$ & $\begin{array}{l}\text { Pearl-Reed } \\
\text { logistic } \\
\text { Model }\end{array}$ & Date & $\begin{array}{l}\text { Quadratic } \\
\text { Model }\end{array}$ & $\begin{array}{l}\text { Pearl- } \\
\text { Reed } \\
\text { logistic } \\
\text { Model }\end{array}$ & Date & $\begin{array}{l}\text { Quadratic } \\
\text { Model }\end{array}$ & $\begin{array}{l}\text { Pearl- } \\
\text { Reed } \\
\text { logistic } \\
\text { Model }\end{array}$ \\
\hline 19 Aug. & 534 & 496 & 12Sept. & 528 & 496 & 08 Oct. & 496 & 496 \\
\hline 20 Aug. & 534 & 496 & 13Sept. & 528 & 496 & 09Oct. & 495 & 496 \\
\hline 19 Aug. & 534 & 496 & 14Sept. & 527 & 496 & 10Oct. & 493 & 496 \\
\hline 21 Aug. & 534 & 496 & 15Sept. & 526 & 496 & 11Oct. & 491 & 496 \\
\hline 22 Aug. & 535 & 496 & 16Sept. & 525 & 496 & 12 Oct. & 489 & 496 \\
\hline 23 Aug. & 535 & 496 & 17Sept. & 524 & 496 & 13 Oct. & 487 & 496 \\
\hline 24Aug. & 535 & 496 & 18Sept. & 523 & 496 & 14 Oct. & 485 & 496 \\
\hline 25Aug. & 535 & 496 & 19Sept. & 522 & 496 & 15 Oct. & 483 & 496 \\
\hline 26Aug. & 535 & 496 & 20Sept. & 521 & 496 & 16 Oct. & 481 & 496 \\
\hline 27Aug. & 535 & 496 & 21Sept. & 520 & 496 & 17 Oct. & 478 & 496 \\
\hline 28Aug. & 535 & 496 & 22Sept. & 519 & 496 & 18 Oct. & 476 & 496 \\
\hline 29Aug. & 535 & 496 & 23Sept. & 518 & 496 & 19 Oct. & 474 & 496 \\
\hline 30Aug. & 534 & 496 & 24Sept. & 516 & 496 & 20 Oct. & 472 & 496 \\
\hline 31Aug. & 534 & 496 & 25Sept. & 515 & 496 & 21 Oct. & 469 & 496 \\
\hline 01 Sept. & 534 & 496 & 26Sept. & 514 & 496 & 22 Oct. & 467 & 496 \\
\hline 02Sept. & 534 & 496 & 27 Sept. & 512 & 496 & 23 Oct. & 464 & 496 \\
\hline 03Sept. & 533 & 496 & 28 Sept. & 511 & 496 & 24 Oct. & 462 & 496 \\
\hline 04Sept. & 533 & 496 & 30 Sept. & 509 & 496 & 25 Oct. & 459 & 496 \\
\hline 05Sept. & 532 & 496 & 01 Oct. & 508 & 496 & 26 Oct. & 457 & 496 \\
\hline 06Sept. & 532 & 496 & 02 Oct. & 506 & 496 & 27 Oct. & 454 & 496 \\
\hline 07 Sept. & 532 & 496 & 03 Oct. & 505 & 496 & 28 Oct. & 452 & 496 \\
\hline 08Sept. & 531 & 496 & 04 Oct. & 503 & 496 & 29 Oct. & 449 & 496 \\
\hline 09Sept. & 530 & 496 & 05 Oct. & 502 & 496 & 30 Oct. & 446 & 496 \\
\hline 10Sept. & 530 & 496 & 06 Oct. & 500 & 496 & 31 Oct. & 443 & 496 \\
\hline 11 Sept. & 529 & 496 & 07 Oct. & 498 & 496 & & & \\
\hline
\end{tabular}




\section{Control Charts}

We employed the use of control charts to monitor and detect shifts in the average number of daily new confirmed cases of COVID-19 in Nigeria. This will help to establish whether the spread of the novel coronavirus is within statistical control in the country.

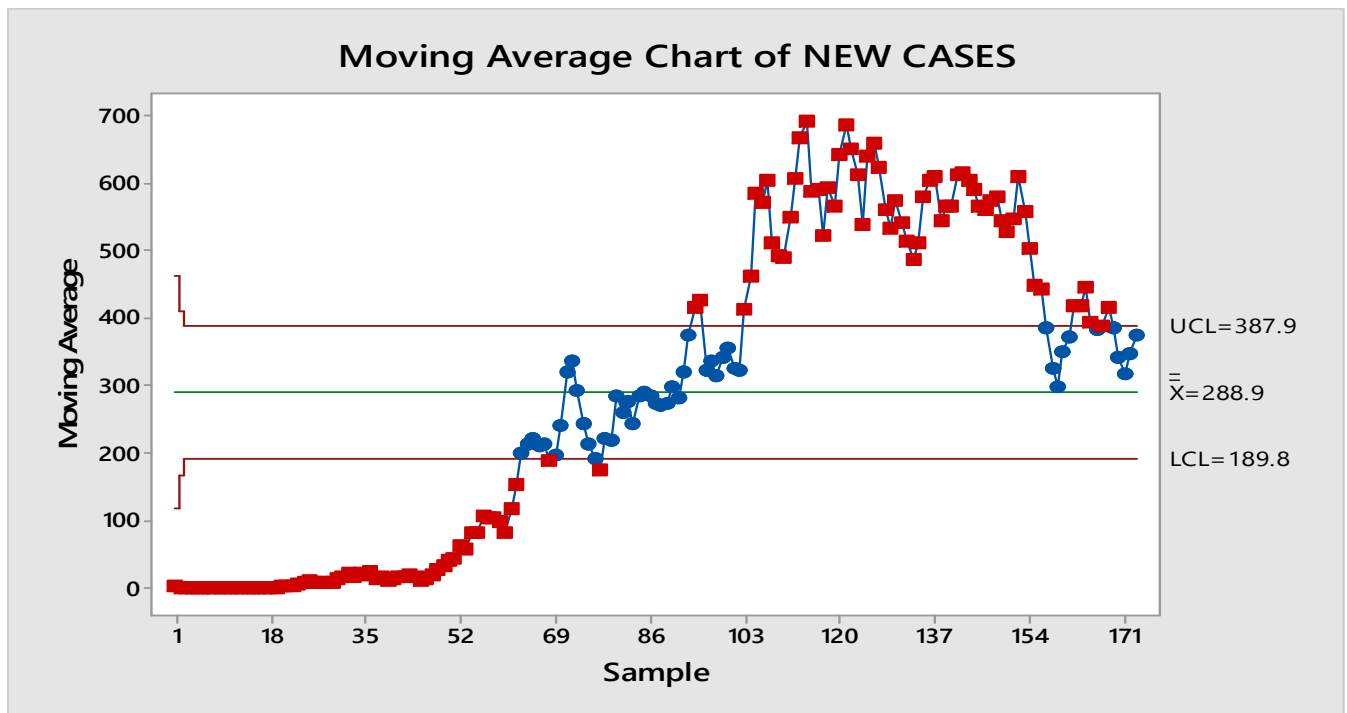

Figure 5: Moving Average control chart for daily lab-confirmed cases of COVID-19 as of $18^{\text {th }}$ August 2020

From figure 5 above, the Moving average control chart plotted with 3-point MA showed that there was a shift in the average number of daily lab-confirmed cases of COVID-19 in Nigeria. This shift occurred on day $94\left(29^{\text {th }}\right.$ May 2020), followed by gross out-of-control points from days 103 to 156. This shows that the average number of daily new confirmed cases of COVID-19 in Nigeria is out of statistical control. However, it was also observed that some points from157 onwards plotted within the control limits which indicates that effort to curb the spread of the virus is yielding some positive results as the average number of daily new confirmed cases is gradually coming into statistical control.

INDIVIDUAL VALUES CONTROL CHART (I-Chart)

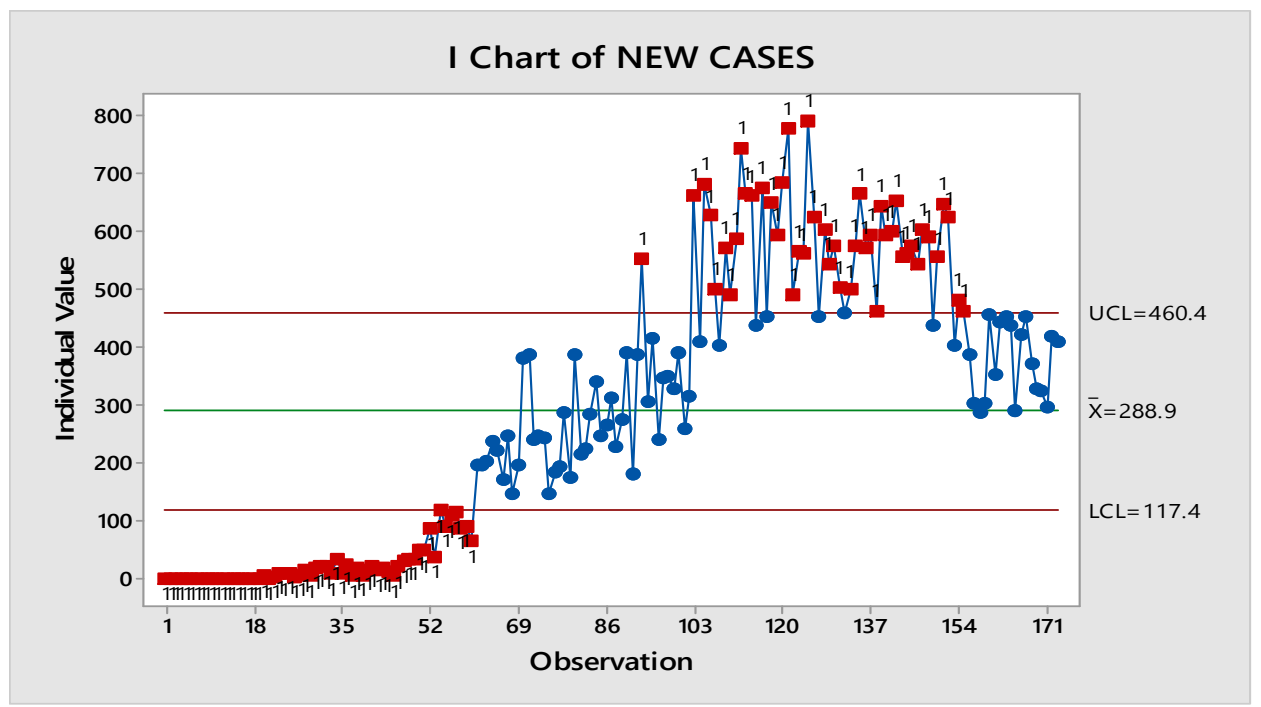

Figure 6: Moving Average control chart for daily lab-confirmed cases of COVID-19 as of $18^{\text {th }}$ August 2020 
From figure 6 above, the Individual values control chart showed that there was a shift in the average number of daily lab-confirmed cases of COVID-19 in Nigeria. This shift occurred at day $93\left(30^{\text {th }}\right.$ May 2020), followed by gross out-of-control points from days 103 to 150 . This shows that the average number of daily new confirmed cases of COVID-19 in Nigeria is out of statistical control. However, it was also observed that samples 153 onwards plotted within the control limits, which indicates that effort to curb the spread of the virus is yielding some positive results as the average number of daily new confirmed cases is gradually coming into statistical control.

\section{EWMA Control Chart}

The Exponentially Weighted Moving Average (EWMA) control chart was plotted for the daily lab-confirmed new cases to monitor the outbreak of the pandemic and determine if the spread is within statistical control.

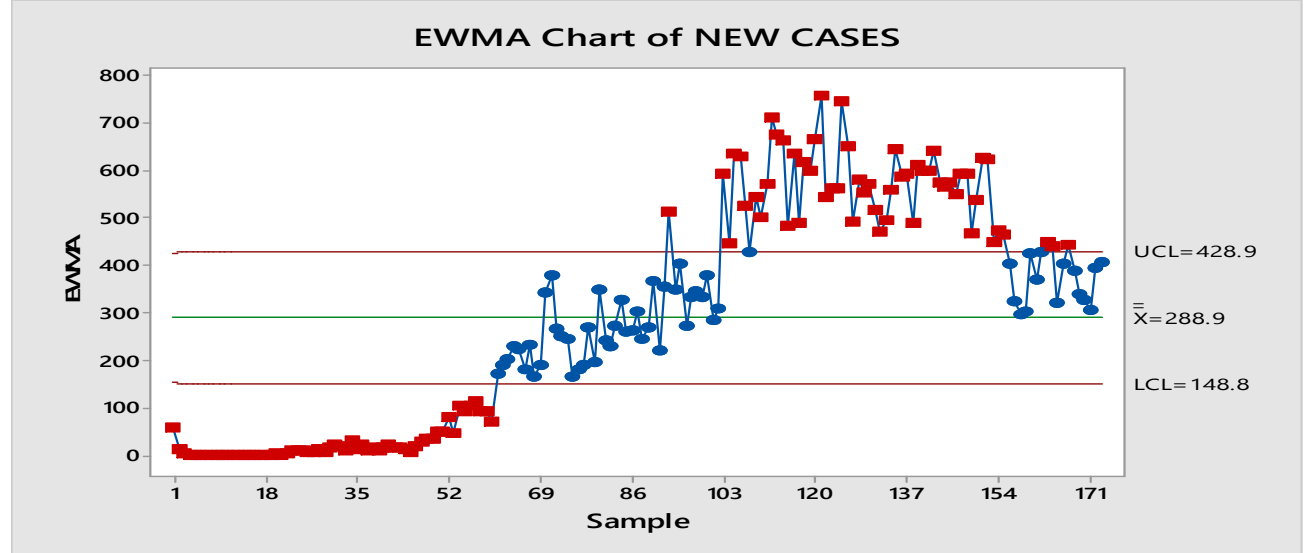

Figure 7: EWMA chart of daily lab-confirmed cases of COVID-19 as of $18^{\text {th }}$ August 2020

Figure 7 above shows the EWMA chart of daily lab-confirmed cases of COVID-19 between $28^{\text {th }}$ February and $18^{\text {th }}$ August 2020 . The chart reveals that the recorded cases of COVID-19 in Nigeria are out of statistical control since the EWMA points from days 93 to 153 were grossly above the upper control limit (UCL). However, plotted EWMA points from days 154 onwards are shown to have returned below the UCL.

\section{CONCLUSION}

This paper presented a study of the spread of COVID-19 in Nigeria from February 28 to August 18, 2020. The two time-series models were fitted to the data. We found out that the Pearl-Reed logistic model showed smaller deviations and therefore judged to be a better model compared to the quadratic model. From the findings of this study, it can also be seen that the spread of COVID19 in the country is out of statistical control. This means that there is a significant shift in the mean (average) of the total new cases recorded daily. This shift becomes evident from days 93 onwards. This indicates that the spread of the virus within the country is still on the increase. The government, therefore, needs to intensify effort to curb the spread of the virus, especially in the high-risk states.

\section{REFERENCES}

"FIRST CASE OF CORONA VIRUS DISEASE CONFIRMED IN NIGERIA". Nigeria Centre for Disease Control. 28 February 2020. Retrieved 10 March 2020.

Maclean, Ruth 17 March 2020. "Africa Braces for Coronavirus, but Slowly". The New York Times. Retrieved 25 March 2020.

Braimah J. O., 2020. On the Monitoring of Coronavirus Disease 2019 (Covid-19) Pandemic Outbreak In Nigeria. African Journal of Biology and Medical Research. 3(2), pp. 33-40.
Ifijeh, Martins 31 January 2020. "FG Sets up Coronavirus Preparedness Group". This Day Newspaper. Retrieved 10 March 2020.

$\begin{array}{ccccc}\text { "Steps } & \begin{array}{c}\text { Nigeria is } \\ \text { coronavirus". MSN. }\end{array} & 29 \text { taking } & \text { prepare } & \text { for } \\ \text { January } & 2020 .\end{array}$ Retrieved 10 March 2020.

Ezigbo, Onyebuchi; Ifijeh, Martins 1 February 2020. "Coronavirus Spread: WHO Lists Nigeria Among High Risk Countries". This Day Newspaper. Retrieved 10 March 2020.

Page, A., 1954.Continuous inspection schemes. Biometrika, Vol. 41, pp. 100-115.

Fajoju O. J., Ikpotokin O., Isere A. O., and Braimah J. O., 2019. "Time Series Analysis of income Generated by Nigerian Postal Services in the Era of Information and Communications Technology". Bulletin of the Science Association of Nigeria. Vol. 30.Pp160 - 173.

Wheeler, D. J., 2000. Understanding Variation: The Key to Managing Chaos. SPC Press, Inc. ISBN 9780-945320-53-1.

Wheeler, D. J., 2009, "When Can We Trust the Limits on a Process Behavior Chart?", Quality Digest, retrieved 2010-02-08.

Wheeler, Donald J., 2009-07-06, "Good Limits from Bad Data", Quality Digest, retrieved 2010-02-08.

Wheeler, D. J., 2009, "Do You Have Digest, retrieved 201002-08
Leptokurtophobia?", Quality 